\title{
OX-CELL HAEMOLYSINS IN HUMAN SERUM
}

\author{
BY \\ G. B. LEYTON \\ From the Provincial Laboratory, Winnipeg, Manitoba, Canada
}

(RECEIVED FOR PUBLICATION MAY 24, 1952)

Ever since Ehrlich and Morgenroth $(1899,1900)$ showed that the naturally occurring lysins were specific antibodies many workers have shown sporadic interest in the power of human sera to agglutinate and haemolyse the erythrocytes of many other vertebrae. Forssman (1911) showed that it was possible to produce haemolysins for sheep corpuscles in the sera of rabbits by injecting them with organs obtained from guinea-pigs, and that the titres of the sera were much higher than were ever found with naturally occurring antibodies. This was the first description of what are now known as heterophile antibodies, and Forssman's work has been confirmed and amplified by many workers, including Taniguchi $(1920,1921,1922)$, Davidsohn (1929, 1930), Davidsohn and Ramsdell (1929), and Browning (1931). All these workers concerned themselves with the theoretical aspect of the antibody and the differentiation of one type of heterophile antibody from another. Most of these workers used agglutination rather than haemolysis as a criterion for the presence of the antibodies, and sheep cells were by far the commonest erythrocyte used in their experiments. Paul and Bunnell (1932) observed that the serum of patients suffering from glandular fever (infectious mononucleosis) showed the presence of agglutinating antibodies for sheep cells to a high titre. Ever since the discovery of this phenomenon the power of patients' sera to agglutinate sheep cells has been used to help in the diagnosis of glandular fever. Changes in the technique of the original test and the introduction of guineapig kidney and boiled ox cells for differential absorption of the Forssman and pseudo-Forssman antibodies by Stuart, Welch, Cunningham, and Burgess (1936) and Davidsohn (1937) have led to a considerable increase in the accuracy of the results obtained. Although Paul and Bunnell used the agglutinating antibodies as the basis of the test that bears their name, it was immediately realized that haemolysing antibodies were also present against the sheep corpuscles as well as against the corpuscles of some other animals. Bailey and
Raffel (1935) conducted experiments to elucidate. something of the nature of both the agglutinating and haemolysing antibodies present in three cases or of glandular fever. They showed that the haemolysins were active against both sheep and ox cells, $\underset{N}{\omega}$ but found little agglutination of ox cells with the $\rightarrow$ sera they used. Since then little attention has been 음 paid to haemolysing antibodies found in human sera in general, and practically no mention of their $z$ affinity for ox cells in particular. In view of the comparatively scant literature on this well- 3 recognized phenomenon and the varying results $\stackrel{\mathbb{\Phi}}{-}$ obtained, it seemed worth while to investigate the $\vec{\theta}$ position more fully.

Preliminary experiments showed that classical cases of glandular fever have in their sera a hig titre of haemolysing antibodies for ox cells. Usirg a $2 \%$ suspension of red cells, all efforts to show the presence of agglutinating antibodies for ox cells in cases of glandular fever were unsuccessful, $\mathbb{Q}$ although attempts were made with cells suspended $\overrightarrow{\overrightarrow{0}}$ in saline, in $30 \%$ albumin, in dextran, and in 3 sorbitol and glycerine. A weak agglutination could sometimes be obtained at a titre of 5 and 10 if the tubes were centrifuged after the cells and sera had been incubated for 15 minutes at $37^{\circ} \mathrm{C}$. 0 The ox cells were agglutinated after exposure to 3 sera from cases of glandular fever by rabbit antihuman globulin prepared as for the Coombs test: $\frac{\text { ? }}{3}$ but also ox-cell absorbed. Even this method was not uniformly successful. However, before any comparison of the activity of various sera can be $\frac{D}{0}$ satisfactorily achieved, even by a haemolytic reaction, it is essential to be able to maintain the $N$ day-to-day sensitivity of the test within small limits. $N$ With this object in view it was decided to inves- $N$ tigate something of the nature of the reactions $\omega$ involved.

\section{Technique}

In any test employing erythrocytes, complement, $\stackrel{\mathcal{P}}{+}$ and a haemolysin there are clearly three variables. $\frac{T}{0}$ Therefore, if we wish to estimate one of these with $\stackrel{\vec{\Phi}}{\circ}$

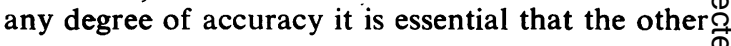


two variables be kept constant or at any rate be so arranged that they do not affect the result of the test. In this investigation it is the haemolysin which is being studied; therefore it was decided first to see how variation in the strength of the red cell suspension and the amount of complement present altered the haemolytic titre of a single specimen of serum. Experiments showed that the haemolytic titre of a human serum for ox cells was inversely proportionate to the concentration of erythrocytes provided that the ratio of erythrocytes to complement was kept constant. When from 1 to 8 M.H.D. (minimum haemolytic doses) of complement were used even slight variation in the amount present altered the haemolytic titre of the serum considerably, but when more than 8 M.H.D. of complement were present no significant alteration of the titre of a serum was observed regardless of how much more complement was present. It was thought that varying the size of the tubes might affect the titres observed, but it was found that a change of at least $50 \%$ in the bore of the tubes made no difference to the results.

These experiments showed that it would be possible to maintain the sensitivity of the test at a constant level, but that it was essential to control the strength of the erythrocyte suspension and concentration of complement. It was therefore decided that in all further experiments, unless stated expressly to the contrary, the following technique would be used:

Erythrocytes.-An approximately $2 \%$ suspension of red cells was made up and standardized as follows: Ox cells, preserved in glucose citrate and not more than three weeks old, were washed three times with $0.9 \%$ sodium chloride, and a suspension a little stronger than $2 \%$ was prepared. Of this suspension, $1 \mathrm{ml}$. was added to $4 \mathrm{ml}$. of $\mathrm{N} / 10 \mathrm{HCl}$ and allowed to stand for 30 minutes, when $5 \mathrm{ml}$. of a $2 \%$ sodium cyanide solution was added. The results were read in a photoelectric colorimeter with a green filter. The result obtained with this percentage of ox cells was very near to the $100 \%$ reading of the standard for the cyanhaemoglobin method used to estimate haemoglobins in the laboratory, and the ox-cell suspension treated as above was diluted to read within $1 \%$ of this standard. A fresh suspension of ox cells was prepared each day. It was realized that this method of standardization only kept the haemoglobin at a constant level, but, since the colour index of the ox bloods employed was fairly constant, the number of red blood corpuscles in the suspensions should have been reasonably constant.

Complement.-Ten minimum haemolytic doses for a 3\% suspension of sheep cells sensitized with 5 M.H.D. of rabbit anti-sheep haemolysin were used. This figure was chosen because it would be within the range where minor variations in estimation would have but a small effect and still keep the amount of guinea-pig serum used within reasonable bounds. The only reason that an amount related to sheep cells rather than to ox cells was employed was because complement was being titrated each day for this percentage of sheep cells for routine complementdeviation tests for syphilis, and thus unnecessary work was avoided.

Test.-Serum was inactivated at $56^{\circ} \mathrm{C}$. for $30 \mathrm{~min}$ utes. Doubling dilutions of serum were made and $0.5 \mathrm{ml}$. placed in a glass tube, 4 in. $\times \frac{1}{2}$ in., to which $0.5 \mathrm{ml}$. of $2 \%$ ox-cell suspension was added. Then $0.5 \mathrm{ml}$. of 10 M.H.D. of complement was added. The tubes were incubated in a $37^{\circ} \mathrm{C}$. water-bath for 15 minutes. A reading was made immediately after removing the rack from the water-bath. The endpoint was considered in the tube showing the nearest to $50 \%$ haemolysis.

To obtain consistent results it was found necessary either to place the tubes in the water-bath immediately after adding the complement or put them in the refrigerator at $4^{\circ} \mathrm{C}$., since haemolysis occurs slowly at room temperature and if this was allowed to continue for long a decrease in the final titre obtained was noted. ("Titre" is used throughout this communication to indicate the reciprocal of the final dilution of the serum before any other reagent is added.)

\section{Experiments}

Although there was no reason to believe otherwise it was thought advisable to prove that the haemolysin was absorbed on to the red cells in the absence of complement, as this method was going to be employed later in the investigation to differentiate the antibodies absorbable by sheep cells. The expected results were obtained because the ox cells sensitized with serum from a patient with glandular fever reacted in an identical manner to sheep cells sensitized with rabbit antisheep haemolysin.

It has been stated (Bailey and Raffel, 1935) that " the titre of haemolysins in the sera of patients suffering from glandular fever for sheep cells and ox cells were both high." It was therefore decided to carry out experiments to see if this was found to be the case with the sera being investigated (Table I).

TABLE I

TITRE OF HAEMOLYSIN FOR SERA TESTED WITH SHEEP AND OX CELLS

\begin{tabular}{l|r|r|r|r|r|r|r|r|r|r|r|r}
\hline No. of sera & 1 & 2 & 3 & 4 & 5 & 6 & 7 & 8 & 9 & 10 & 11 & 12 \\
\hline Ox cells $\ldots$ & 320 & 160 & 80 & 80 & 640 & 320 & 40 & 80 & 640 & 1,280 & 80 & 160 \\
\hline Sheep cells & 10 & 20 & 10 & 10 & 40 & 20 & 40 & 10 & 10 & 20 & 20 & 10 \\
\hline
\end{tabular}


The titrations for sheep and ox cells were carried out at the same time and by exactly the same technique, so the results suggest that the titre for ox cells is much higher than the titre for sheep cells in most cases of glandular fever.

In view of the fact that the sheep cells are agglutinated by human sera in a multitude of conditions it was thought possible that these cells might well absorb the haemolysins for ox cells, although the sheep cells themselves were not haemolysed. By following the technique of Dacie (1950) for the absorption of sheep-cell agglutinins by boiled ox cells, but using fresh sheep cells instead of boiled ox cells, no significant reduction in ox-cell haemolysins could be demonstrated. By using the more delicate method of diluting the sera to titre and then absorbing with a large volume of sheep cells and assessing the reduction of the amount of haemolysins obtained by a photoelectric colorimeter it seems as if a very slight absorption does occur.

During the above experiments it was noted that agglutination of the sheep cells in the presence of complement did not appear to absorb the latter substance. Further discussion of this phenomenon is not going to be considered in this paper, as it is to be the substance of a further report. For completeness sera were then tested by the standard method of differential absorption (Dacie, 1950). As was expected, absorption of the serum by guinea-pig kidney made practically no difference to the titre of the ox-cell haemolysins present, while absorption with boiled ox cells invariably removed all of the ox cell haemolysins present in the serum.

The aforementioned experiments showed that haemolysins for ox cells could be determined accurately and consistently and that they were different from sheep cell agglutinins, since even when the sheep-cell agglutinins were completely absorbed ox-cell haemolysins were still present.. It was therefore decided to test for these antibodies in all sera submitted to the laboratory for testing for the presence of heterophile antibodies, for complement-fixing antibodies for encephalitis, mumps, influenza, and lymphocytic choriomeningitis, and also on all sera submitted for investigation for cold agglutinins. This investigation has been carried out for the last 18 months. In addition, during the first few months of the experiment, 2,000 sera submitted for routine testing for syphilis (premarital blood tests) were also examined. Table II shows the number of sera of each titre found in a number of conditions.

These results indicate that in by far the majority of the population the titre of ox-cell haemolysins
TABLE II

NO. OF SERA OF EACH TITRE IN CERTAIN CONDITIONS

\begin{tabular}{|c|c|c|c|c|c|c|c|c|c|c|}
\hline \multirow[b]{2}{*}{ Condition } & \multirow{2}{*}{$\begin{array}{c}\text { No. of } \\
\text { Sera } \\
\text { Tested }\end{array}$} & \multicolumn{9}{|c|}{ Titre of Ox-cell Haemolysins } \\
\hline & & $\begin{array}{c}\text { Under } \\
10\end{array}$ & 20 & 40 & 80 & 160 & 320 & 640 & 1,280 & 2,560 \\
\hline $\begin{array}{l}\text { Premarital } \\
\text { blood tests }\end{array}$ & 2,000 & 1,998 & & & 1 & & & & 1 & \\
\hline $\begin{array}{l}\text { Sera contain- } \\
\text { ing cold } \\
\text { agglutinins } \\
\text { to a titre } \\
\text { above } 160\end{array}$ & 26 & 21 & 4 & 1 & & & ! & & 1 & \\
\hline Leukaemia & 12 & 10 & & 1 & $\overline{1}$ & & & & 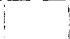 & \\
\hline Cancer $\quad$. & 100 & 98 & 1 & 1 & & & & & & \\
\hline $\begin{array}{c}\text { Infective } \\
\text { hepatitis }\end{array}$ & 23 & 22 & 1 & . & & & & & & 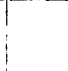 \\
\hline
\end{tabular}

in the sera when tested by the previously mentioned method is under 10 and it is exceedingly exceptional for it to be over 40 .

\section{Results for Glandular Fever}

During the 18 months under review 987 sera were received for testing for heterophile antibodies. Eight hundred and nine of these gave a negative result by the standard method of performing the $\mathrm{N}$ heterophile antibody test (Dacie, 1950). Of these 809, 799 showed an ox-cell haemolysin titre less than 20 . Of the remaining 178 sera tested, 161 gave a positive Paul-Bunnell reaction, i.e., that the sheep cell agglutinin titre was reduced less than three tubes by the absorption with guinea-pig kidney and that absorption with boiled ox cells reduced the titre of the serum to one-tenth of the original figure. Of these 161 sera, all showed a titre of ox-cell haemolysins of 40 or above. Table III shows the number of sera of each titre.

TABLE III

NO. OF SERA OF EACH TITRE IN 161 SERA

\begin{tabular}{l|r|r|r|r|r|r|r|}
\hline Titre of sera .. & 40 & 80 & 160 & 320 & 640 & 1,280 & 2,560 \\
\hline Number of sera & 8 & 51 & 35 & 30 & 25 & 9 & 3 \\
\hline
\end{tabular}

The remaining cases gave atypical serological results. Table IV shows the results obtained in $\stackrel{N}{\sigma}$ a few of these cases.

On a number of these sera weekly estimations of $N$ the antibody titres were made in an endeavour to discover whether the ox cell haemolysins and sheep cell agglutinins appeared and regressed at the same rate. No entirely consistent results were obtained, but in by far the majority of the cases examined the titre of the ox-cell haemolysins began to rise ${ }_{0}^{-}$ earlier and regressed more slowly than the sheep- $\overrightarrow{\mathbb{D}}$ cell agglutinins. 
Table IV

\begin{tabular}{|c|c|c|c|c|c|}
\hline $\begin{array}{l}\text { Case } \\
\text { No. }\end{array}$ & Date & $\begin{array}{c}\text { Sheep } \\
\text { Cell } \\
\text { Unabsorbed }\end{array}$ & $\begin{array}{c}\text { Absorbed } \\
\text { Guinea-pig } \\
\text { Kidney }\end{array}$ & $\begin{array}{l}\text { Absorbed } \\
\text { Boiled } \\
\text { Ox Cells }\end{array}$ & $\begin{array}{c}\text { Ox Cell } \\
\text { Haemolysin } \\
\text { Titre }\end{array}$ \\
\hline 1 & $\begin{array}{r}4 / 8 / 51 \\
11 / 8 / 51 \\
2 / 9 / 51\end{array}$ & $\begin{array}{l}5,120 \\
2,560 \\
1,280\end{array}$ & $\begin{array}{l}2,560 \\
2,560 \\
1,280\end{array}$ & $\begin{array}{l}5,120 \\
2,560 \\
1,280\end{array}$ & $\begin{array}{l}320 \\
320 \\
160\end{array}$ \\
\hline 2 & $\begin{array}{l}11 / 12 / 50 \\
21 / 12 / 50\end{array}$ & $\begin{array}{l}1,280 \\
2,560\end{array}$ & $\begin{array}{l}1,280 \\
1,280\end{array}$ & $\begin{array}{l}640 \\
640\end{array}$ & $\begin{array}{l}20 \\
20\end{array}$ \\
\hline 3 & $\begin{array}{r}21 / 5 / 51 \\
9 / 6 / 51\end{array}$ & $\begin{array}{l}1,280 \\
2,560\end{array}$ & $\begin{array}{l}40 \\
20\end{array}$ & $\begin{array}{l}40 \\
20\end{array}$ & $\begin{array}{c}\text { Less than } 5 \\
,, \quad, \quad 5\end{array}$ \\
\hline 4 & $\begin{array}{r}6 / 5 / 51 \\
20 / 5 / 51\end{array}$ & $\begin{array}{r}20 \\
320\end{array}$ & $\begin{array}{r}20 \\
\cdot 320\end{array}$ & $\begin{array}{l}10 \\
40\end{array}$ & $\begin{array}{r}80 \\
320\end{array}$ \\
\hline 5 & $\begin{array}{r}9 / 10 / 51 \\
10 / 11 / 51\end{array}$ & $\begin{array}{l}5,120 \\
2,560\end{array}$ & $\begin{array}{l}2,560 \\
2,560\end{array}$ & $\begin{array}{r}1,280 \\
640\end{array}$ & $\begin{array}{l}320 \\
640\end{array}$ \\
\hline 6 & $\begin{array}{r}7 / 8 / 51 \\
15 / 8 / 51\end{array}$ & $\begin{array}{r}20,480 \\
5,260\end{array}$ & $\begin{array}{r}20,480 \\
5,260\end{array}$ & $\begin{array}{r}20,480 \\
1,280\end{array}$ & $\begin{array}{l}5,120 \\
1,280\end{array}$ \\
\hline 7 & $\begin{array}{r}7 / 6 / 50 \\
16 / 6 / 50\end{array}$ & $\begin{array}{l}1,280 \\
2,560\end{array}$ & $\begin{array}{l}160 \\
320\end{array}$ & $\begin{array}{l}160 \\
320\end{array}$ & $\begin{array}{c}\text { Less than } 5 \\
,,, \quad 5\end{array}$ \\
\hline
\end{tabular}

\section{Discussion}

The preceding experiments give some information concerning the presence of ox-cell haemolysins in the serum of man, and make some speculation concerning their nature possible. Since ox-cell haemolysins are not absorbed to any extent by sheep cells, and are sometimes absent even when sheep-cell agglutinins are absorbed by boiled ox cells (Table IV, No. 3), and haemolysins for sheep cells are only present at low titres and ox-cell agglutinins almost completely absent, it is therefore suggested that agglutinins of one type and haemolysins of another type are found in the sera of patients suffering from glandular fever. It seems probable that the haemolysins and agglutinins are not merely different manifestations of the same antibody, but different antibodies probably formed in response to different antigens. The absorption of the sera with guinea-pig kidney and boiled ox cells does not help to elucidate the problem, since it shows that the ox-cell haemolysin is not a Forssman antibody and that heating of the ox cells does not destroy the antigenic complex concerned with haemolysis.

These suggestions are contrary to the findings of most previous workers, and bring up the question of whether or not glandular fever with its widely varying clinical manifestations is a single entity or a multiplicity of conditions. The serological results observed in the atypical cases in this investigation give strong support to the latter hypothesis.

Table II shows conclusively that titres of ox-cell haemolysins of over 20 by the technique employed will not frequently be found in the population in general, nor in patients suffering from atypical pneumonia, haemolytic anaemia, leukaemia, infective hepatitis, and carcinoma. Serum sickness is a rare disease these days, but the two cases available only showed a titre of 10 and 20 respectively. The number of sera with titres of over 20 found amongst the 2,000 presumably healthy people (those about to be married) and in the abovementioned diseases is so low that it is by no means unlikely that these people had previously suffered from glandular fever or had received subinfective doses of the virus, since this is a very common disease in the district from which many of the sera were received. Whether or not this be true, it is not suggested that ox-cell haemolysins are found only in glandular fever, since they appear to be a heterophile antibody and as such must be capable of being produced by many stimulating agents.

Table III shows the titres for cases diagnosed clinically and serologically as classical cases of glandular fever. The figures in this table leave little doubt that cases of glandular fever usually develop ox-cell haemolysins in their sera to a titre many times that found in normal sera, and that the height of the titre is sufficient for its titration to be of help in the diagnosis of this disease. The ox-cell haemolysins usually appear earlier and as, or even more, consistently than the antibodies estimated in the Paul-Bunnell reaction. It would seem therefore that ox-cell haemolysins are a more reliable guide to the presence of glandular fever than sheep cell agglutinins, but that in difficult cases more information can be obtained by doing both tests than either separately.

\section{Conclusions}

In all tests where there are antibodies present, but at a low titre in normal serum, it is difficult to decide what titre to consider significant when the titre of these antibodies is raised in disease. This is also the case with ox-cell haemolysins. Naturally the most satisfactory method of diagnosis is to obtain one serum early in the disease and one about a fortnight later and compare the titres. For clinical reasons such a procedure is usually unsatisfactory, as an immediate diagnosis is generally required. If the technique described in this paper is employed it seems certain that a titre of 40 or over can be considered diagnostic of glandular fever in the presence of suitable clinical and haematological findings. A titre of 160 or over is very suggestive of glandular fever without much clinical evidence of the disease. If two or three specimens received at weekly intervals show a titre of less than 20 it is most unlikely that the patient has glandular fever. 
It seems as if the estimation of ox-cell haemolysins in the sera is a more valuable procedure in aiding the clinician to diagnose glandular fever than the present Paul-Bunnell reaction even with differential absorption. It also has the advantage of giving a quicker result and is much easier to perform. In difficult cases it is suggested that both the ox-cell haemolysins be estimated and a Paul-Bunnell reaction with differential absorption be carried out.

\section{Summary}

A standard technique for estimation of oxcell haemolysins in human sera is described.

The presence of ox-cell haemolysins to a titre much higher than that found in normal sera is a consistent finding in patients with glandular fever.
It is suggested that an estimate of the ox-cell haemolysins present in the serum is a better aid to the diagnosis of glandular fever than the PaulBunnell reaction.

\section{REFERENCES}

Bailey, G. H., and Raffel, S. (1935). J. clin. Invest., 14, 228.

Browning, C. H. (1931). In "A System of Bacteriology in Relation to Medicine." Spec. Rep. Ser. med. Res. Coun. Lond., vol. 6, p. 501

Dacie, J. V. (1950). Practical Haematology. London.

Davidsohn I (1929). J. Immunol., 16, 259.

(1930). Ibid., 18, 31 .

(1937). J. Amer. med. Ass., 108, 289.

and Ramsdell, S. G. (1929). J. Immunol., 17, 365.

Ehrlich, P., and Morgenroth, J. (1899). Berl. klin. Wschr., 36, 481. (1900). Ibid., 37, 453, 681.

Paul, J. R., and Bunnell, W. W. (1932) Amer. J. med. Sci., 183, 90. Paul, J. R., and Bunnell, W. W. (1932). Amer. J. med. Sci., 183, 90. Arch. intern. Med., 58, 512 .
Art,

Taniguchi, T. (1920). J. Path. Bact., 23, 368.

- (1921). Ibid., 24, 122. 